\title{
Assessment of risk factors in metastatic/recurrent tall cell variant of papillary thyroid carcinoma
}

\author{
Ocena czynników ryzyka w odmianie wysokokomórkowej przerzutowego/ \\ /nawrotowego raka brodawkowatego tarczycy
}

\author{
Kursat Okuyucu, Engin Alagoz, Semra Ince, Nuri Arslan \\ Gulhane Training and Research Hospital, Department of Nuclear Medicine, Etlik, Ankara, Turkey
}

\begin{abstract}
Introduction: Papillary thyroid carcinoma (PTC) is the most common malignant thyroid tumour. A great majority of the cases live a disease-free life with quite favourable prognosis. There are lots of variants of PTC, and a few of them exhibit aggressive behaviour. A typical example is the tall cell variant (TCV). Patients experience a greater incidence of recurrence, nodal and extranodal metastases, and tumour-associated mortality than in other variants of PTC. Studies related to TCV almost always compared it with its patient population of PTC according to risk factors and clinicopathological features. The aim of this study is to evaluate the risk factors in metastatic/recurrent TCV. Materials and methods: This is a retrospective cohort study of 1813 patients with differentiated thyroid carcinoma treated with radioiodine between 1992 and 2011. Fifty-six of these patients are TCV. Thirty-four of them developed metastasis/recurrence, and 22 lived a disease-free life during a follow-up time of 4-23 years. We evaluated the risk factors in these metastatic and non-metastatic subgroups. Results: We found tumour size, pre-ablation thyroglobulin level, vascular invasion, pre-ablation central and lateral cervical lymph node metastasis, pre-ablation lung metastasis, and stage-independent risk factors. However, age, pre-ablation thyroglobulin level, and stage appeared together as striking factors impacting metastasis in multivariate analysis.

Conclusion: Higher ablation doses up to $250-300 \mathrm{mCi}$ should be administered to TCV patients having advanced stage (III, IV), moderately high pre-ablation thyroglobulin level (over $400 \mathrm{ng} / \mathrm{ml}$ ), and older age (over 52 years) especially with large tumour size (over $3.5 \mathrm{~cm}$ ) and initial cervical lymph node metastasis. (Endokrynol Pol 2017; 68 (6): 623-630)
\end{abstract}

Key words: tall cell variant, papillary thyroid carcinoma, prognostic risk factors

\section{Streszczenie}

Wstęp. Rak brodawkowaty tarczycy (papillary thyroid carcinoma, PTC) jest najczęstszym nowotworem złośliwym tego narządu. U przeważającej większości chorych możliwe jest całkowite wyleczenie, a rokowanie jest dobre. Występuje wiele odmian PTC, spośród których nieliczne są bardziej agresywne. Typowym przykładem takich nowotworów jest odmiana wysokokomórkowa (tall cell variant, TCV). Cechuje się ona częstszym występowaniem wznów, przerzutów do węzłów chłonnych i pozawęzłowych oraz większą śmiertelnością z powodu choroby nowotworowej niż inne odmiany PTC. Badania dotyczące TCV niemal zawsze mają na celu porównanie tej grupy chorych z populacją chorych na PTC w odniesieniu do czynników ryzyka oraz parametrów klinicznych i patomorfologicznych. Celem niniejszego badania jest ocena czynników ryzyka w przerzutowym/nawrotowym TCV.

Materiał i metody. Było to retrospektywne badanie kohortowe obejmujące 1813 chorych ze zróżnicowanym rakiem tarczycy leczonych jodem promieniotwórczym w latach 1992-2011. U 56 osób z tej grupy rozpoznano TCV. U 34 z nich stwierdzono przerzut/nawrót, a w przypadku 22 chorych potwierdzono przeżycie wolne od choroby przez okres 4-23 lat. Autorzy ocenili czynniki ryzyka w podgrupach chorych z przerzutami i bez przerzutów.

Wyniki. Stwierdzono, że niezależnymi czynnikami ryzyka są wielkość guza, stężenie tyreoglobuliny przed ablacją, unaczynienie guza, przerzuty to węzłów chłonnych szyjnych środkowych i tylnych oraz do płuc przed ablacją, a także stopień zaawansowania choroby. Jednak najważniejszymi czynnikami ryzyka przerzutów w analizie wieloczynnikowej okazały się wiek, stężenie tyreoglobuliny przed ablacją i stopień zaawansowania choroby nowotworowej.

Wnioski. U chorych z TCV w zaawansowanym stadium (III, IV), z wysokimi stężeniami tyreoglobuliny ( $>400 \mathrm{ng} / \mathrm{ml}$ ) i w starszym wieku (> 52 lata), a zwłaszcza u osób z dużym rozmiarem guza $(>3,5 \mathrm{~cm})$ i obecnymi przerzutami do węzłów chłonnych szyjnych, należy stosować wyższe dawki ablacyjne wynoszące do 250-300 mCi. (Endokrynol Pol 2017; 68 (6): 623-630)

Słowa kluczowe: odmiana wysokokomórkowa, rak brodawkowaty tarczycy, prognostyczne czynniki ryzyka

\section{Introduction}

Papillary thyroid carcinoma (PTC) is the most frequent endocrine malignancy and the most common malignant thyroid tumour. A great majority of cases live a disease-free life with good prognosis. There are many variants of PTC, and only a few of them exhibit aggressive behaviour. A typical example is the tall cell variant (TCV). TCV frequently presents itself with extra-thyroidal disease. Patients with TCV experience 
greater incidence of recurrence, nodal and extranodal metastases, and tumour-associated mortality than the other variants of PTC $[1,2]$. These metastases are usually seen in cervical lymph nodes. Distant metastatic sites for TCV are lungs, bones, and rarely brain and liver.

TCV is composed of tall papillary epithelial cells having a height at least two-times greater than the width, and elongated hyperchromatic nuclei oriented towards the basement membrane in a substantially eosinophilic cytoplasm containing a portion minimally larger than $30 \%$ of the cells within the tumour [2,3]. The incidence of TCV has been reported to be between $3.8 \%$ and $10.4 \%$ in published series $[1,4,5]$. The major controversy in terms of the diagnostic classification of a thyroid cancer as TCV is the quantity of tall cell pattern in the tumour $[6,7]$. According to the $\mathrm{WHO}$, tall cells should compose at least $30-50 \%$ of the tumour for classifying a tumour as TCV $[8,9]$.

Although there are some studies indicating that poor prognosis in this disease is associated with stage, grade, and age over 50 years, rather than histology, TCV is generally accepted as an independent poor prognostic factor in the literature $[1,3,6,7]$. These tumours occur in older ages (average age of occurrence is 55 years), show gross extra-thyroidal extension and vascular invasion, and they are generally larger tumours $(4 \mathrm{~cm}$ on average) than well-differentiated PTC $[9,10]$. Its malignant behaviour was attributed to these properties initially. But later on, it was noticed that metastasis could also be seen in intra-glandular TCV without extra-thyroidal extension, in tumours even smaller than $1.5 \mathrm{~cm}$ or in younger cases. Currently there are no studies with enough samples and long-term follow-up data showing the real impact of these or other risk factors on metastatic potential.

The reason for the aggressiveness associated with molecular base, genetic, and tumoural factors is not known. Overexpression of Mucl1 and type IV collagenase in these tumours may be responsible for the invasive character by degrading stroma [11-13]. A higher prevalence of activating point mutation B-RAF rather than PTC may also be a reason $[14,15]$. It was shown that any subtype of PTC with B-RAF mutation has more extra-thyroidal extension, LN metastasis, and higher stage than B-RAF negative ones $[8,16]$. TCV is generally sensitive to radioactive iodine (I-131, RAI) $[10,17] .20 \%$ of FDG/PET-positive, radioiodine-negative tumours are TCV, and $88 \%$ of I-131 refractory tall cell variants have extra-thyroidal extension $[11,18]$. The aim of the study is to evaluate the risk factors in metastatic/ /recurrent TCV of PTC. This is the first study in literature comparing metastatic and non-metastatic TCV based on predefined risk factors.

\section{Material and methods}

This is a retrospective cohort study. 1813 patients with differentiated thyroid carcinoma (DTC) were treated with I-131 between 1992 and 2011. They were followed-up until 2015 (during a period of 4-23 years) by the Nuclear Medicine Department of Gulhane Training and Research Hospital, Ankara, Turkey. Fifty-nine patients were confirmed pathologically as TCV between 1992 and 2011. TCV diagnosis was established pathologically according to WHO classification criteria on the basis of tall cell pattern dominating more than $30 \%$ of the tumoural area. Tall cell pattern is characterised by being at least twice as tall as its width, having an eosinophilic cytoplasm and a hyperchromatic basilar nucleus. Histology slides were re-examined by another experienced pathologist for confirmation. Three cases of 59 patients were excluded from the study because of inadequate follow-up. Patients diagnosed as TCV after 2011 were not enrolled in the study.

All patients underwent bilateral total thyroidectomy (plus radical neck dissection if there was cervical LN metastasis) after the histopathological diagnosis. RAI ablation treatment was planned according to tumour size (TS), multifocality (MF), thyroid capsule invasion (CI), extra-thyroidal extension (ETE), vascular invasion (VI), and existence of $\mathrm{LN}$ and/or distant metastasis, and it was scheduled 4-6 weeks after the surgery or cessation of thyroxin replacement therapy (TSH levels should be at least over $30 \mathrm{mIU} / \mathrm{L}$ ). Neck ultrasonography (USG) was used to identify possible cervical LN metastasis and/or residual thyroid tissue in the thyroid bed; and serum thyroid stimulating hormone (TSH), thyroglobulin (Tg), anti-Tg were measured 1 to 24 hours before the ablating RAI treatment. A post-treatment I-131 wholebody screening scintigraphy (RxWBS) was performed for all the cases five days after the RAI treatment. If any uptake in regions consistent with lungs or bones was observed, they were considered distant organ metastases and were taken into account for staging. After primary treatment, all patients received thyroxine hormone replacement therapy in suppressive doses. Patients were followed by serum $\mathrm{Tg}$, anti-Tg, $\mathrm{TSH}$ levels, and neck USG every six months in the first two years and then on a yearly basis, to detect local and/or distant metastasis. Whole-body screening test with $185 \mathrm{MBq}$ (5 mCi) I-131 (DxWBS) was performed six months (for assessing ablation response), one year, two years, and five years after the treatment. Other imaging techniques such as X-ray, computed tomography (CT), high-resolution computed tomography (HRCT), magnetic resonance imaging (MRI), bone scintigraphy, positron emission tomography (FDG-PET from 2006 to 2010), and FDG-PET/CT (from 2010) were performed when needed. LNs causing a suspicion of metastasis as a result of USG follow-up were 
examined histologically with fine-needle aspiration biopsy and excised after confirmation or excised directly for histopathological confirmation followed by high-dose RAI treatment. A significant increase in Tg levels (over $10 \mathrm{ng} / \mathrm{ml}$ ) in the follow-up without a demonstrable metastatic foci detected by routine imaging methods was considered as a possible metastasis, and therefore other imaging tests were performed for further investigation. The cases were staged according to the seventh edition of AJCC. The cases followed-up inadequately or for less than four years were excluded from the study.

The files of TCV patients were examined retrospectively. Patients were divided into two groups according to follow-up data. Cases having distant metastases (lung and/or bone, brain, liver), LN metastases (regional and/ /or distant), and/or local recurrence during the follow-up (after initial thyroid surgery and ablative I-131 therapy) formed the metastatic/recurrent group (MG). Those not having metastasis/recurrence formed the non-metastatic group (NMG). The evaluated risk factors are age, sex, TS, MF, CI, ETE, VI, LN, existence of a distant metastasis before the ablation treatment (PACLNM: pre-ablation central lymph node metastasis, PACLLNM: pre-ablation cervical lateral lymph node metastasis, PALM: preablation lung metastasis, PABM: pre-ablation bone metastasis), PAsTg: pre-ablation Tg level (1 to 24 hours before the ablation treatment), and the stage. These risk factors were compared in MG and NMG. The existence of ETE was accepted as tumoural infiltration beyond the thyroid capsule (perithyroidal adipose tissue, muscles, tracheal invasion, carotid vessel invasion). Overall survival (OS) was defined as the time from diagnosis to death due to the disease itself or until the last follow-up. Disease-free survival (DFS) was defined as the time from diagnosis to the detection of relapse or until the last follow-up.

The whole data were analysed by Statistical Package for Social Science (SPSS 15.0, Chicago, IL) software. Number, percentage, mean, median, standard deviation (SD), and minimum (min) and maximum (max) values were used for the description of data analysis. Accordance of continuous variables to normal distribution was measured with Kolmogorov-Smirnov test. Student's $t$ (age) or Mann Whitney-U (TS, PAsTg) test was used for continuous variables; and Chi square (PALM, PABM) or Fisher's exact (sex, MF, CI, ETE, VI, PACLNM, PACLLNM and stage) test for categorical variables in the comparisons between groups. Backward LR (logistical regression) analysis was performed for clarification of risk factors that affect the development of metastasis. Values of $p<0.05$ were accepted as statistically significant. Informed consent was deemed as a retrospective study using records, documents, and data of patients referred to our clinic for I-131 therapy and later follow-up. This study was approved by our Institutional Review Board Ethics Committee.

\section{Results}

Fifty-six patients with TCV were followed-up for a duration of 4-23 years, and TCV incidence was 3.2\% in our DTC patient population. Mean follow-up duration of patients was $97.5 \pm 42$ months (8-190 months). Mean follow-up duration was $105 \pm 37$ months (47-178 months) in the NMG and 92.5 \pm 44 months (8-190 months) in the MG. Mean I-131 dose administered to patients was $11396 \pm 8954 \mathrm{MBq}(2775-48100 \mathrm{MBq})$. Mean I-131 dose administered was $5920 \pm 1776 \mathrm{MBq}$ (2775-11100 MBq) in the NMG and $14948 \pm 9990 \mathrm{MBq}$ (3700-48100 MBq) in the MG.

Mean age (at diagnosis), mean TS, and mean PAsTg of patients were $49 \pm 15.5$ years (19-80 years), $27.5 \pm$ $19.5 \mathrm{~mm}(4-85 \mathrm{~mm})$, and $290.5 \pm 90 \mathrm{ng} / \mathrm{ml}$, respectively. The values of these continuous variables belonging to groups and their comparisons are summarised in Table I. Sixty-six per cent of the patients were female and $34 \%$ were male (female/male ratio: 1.95 ). The tumour was multifocal in $46.5 \%$ of the patients. CI was positive in $64 \%$ of the patients. ETE was seen in $35.5 \%$ of the patients. $37.5 \%$ of the patients were VI $(+) .37 .5 \%$ of the patients had central LN metastasis before ablation therapy. $44.5 \%$ of the cases had lateral LN metastasis before ablation therapy. PALM rate was 7/56 (12.5\%) and PABM was 5/56 (9\%). $48 \%$ of the patients were at stage I, $11 \%$ at stage II, $11 \%$ at stage III, and $30 \%$ at stage IV. The bar graphic in Figure 1 presents the categorical variables of MG and NMG. These categorical risk

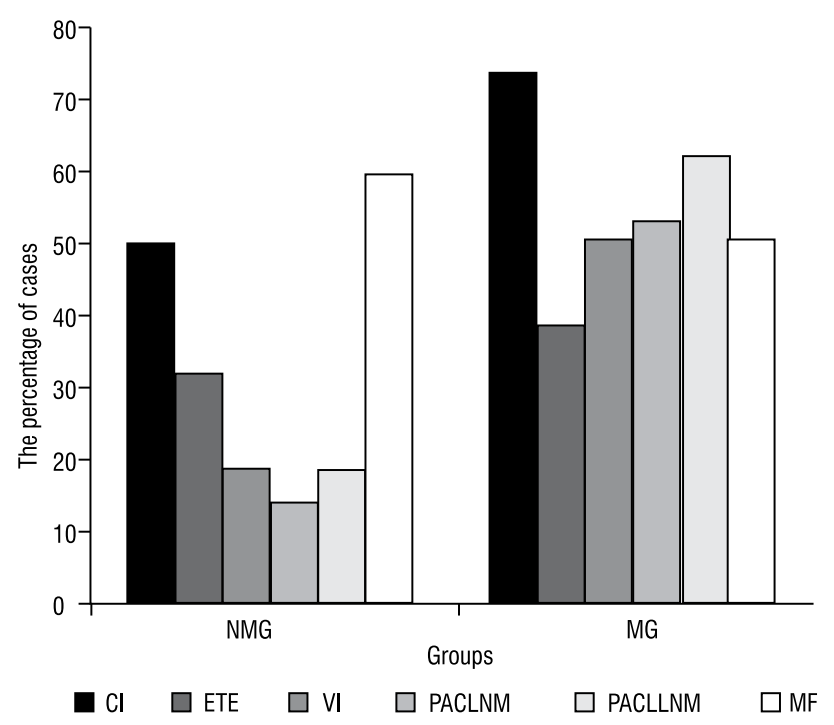

Figure 1. Bar graphic of metastatic/recurrent group (MG) and non-metastatic group (NMG) by CI, ETE, VI, PACLNM, PACLLNM, and MF

Rycina 1. Wykres stupkowy przedstawiajacy CI, ETE, VI, PACLNM, PACLLNM i MF w grupach z przerzutem/nawrotem (MG) i bez przerzutu/nawrotu (NMG) 
Table I. Comparison of metastatic/recurrent and non-metastatic group by age, tumour size, PAsTg

Tabela I. Porównanie wieku, wielkości guza i PAsTg w grupach z przerzutem/wznowq i bez przerzutu

\begin{tabular}{llll}
\hline \multirow{2}{*}{ Variables } & Metastatic/recurrent group & Non-metastatic group & \multirow{2}{*}{ p value } \\
\cline { 2 - 4 } & Mean \pm SD & Mean \pm SD & $0.165^{\mathrm{a}}$ \\
\hline Age (year) & $51.4 \pm 14.4$ & $45.4 \pm 17.3$ & $0.007^{*}$ \\
\hline Tumour size $[\mathrm{mm}]$ & $31.4 \pm 19.1$ & $21.2 \pm 19.0$ & $<0.001^{*}$ \\
\hline PAsTg $[\mathrm{ng} / \mathrm{ml}]$ & $403.7 \pm 269.7$ & $160.2 \pm 48.0$ & \\
\hline
\end{tabular}

aStudent $\mathrm{t}$ test*: Mann Whitney-U test; PAsTg — pre-ablation Tg levels immediately prior to the treatment

Table II. Comparison of metastatic/recurrent and non-metastatic group by other variables

Tabela II. Porównanie innych zmiennych w grupach z przerzutem/wznowq i bez przerzutu

\begin{tabular}{|c|c|c|c|c|c|c|}
\hline \multirow[t]{2}{*}{ Variables } & & \multicolumn{2}{|c|}{ Metastatic/recurrent group } & \multicolumn{2}{|c|}{ Non-metastatic group } & \multirow[t]{2}{*}{$\mathbf{p}^{\mathrm{a}}$} \\
\hline & & n & $\%$ & n & $\%$ & \\
\hline \multirow[t]{2}{*}{ Sex } & Male & 14 & 41.2 & 5 & 22.7 & 0.154 \\
\hline & Female & 20 & 58.8 & 17 & 77.3 & \\
\hline \multirow[t]{2}{*}{ Multifocality } & 1 focus & 17 & 50.0 & 13 & 59.1 & 0.505 \\
\hline & 2 or over & 17 & 50.0 & 9 & 40.9 & \\
\hline \multirow[t]{2}{*}{ Capsule invasion } & Exist & 25 & 73.5 & 11 & 50.0 & 0.073 \\
\hline & Not exist & 9 & 26.5 & 11 & 50.0 & \\
\hline \multirow[t]{2}{*}{ Extra-thyroidal extension } & Exist & 13 & 38.2 & 7 & 31.8 & 0.625 \\
\hline & Not exist & 21 & 61.8 & 15 & 68.2 & \\
\hline \multirow[t]{2}{*}{ Vascular invasion } & Exist & 17 & 50.0 & 4 & 18.2 & 0.016 \\
\hline & Not exist & 17 & 50.0 & 18 & 81.8 & \\
\hline \multirow[t]{2}{*}{ PACLNM } & Exist & 18 & 52.9 & 3 & 13.6 & 0.003 \\
\hline & Not exist & 16 & 47.1 & 19 & 86.4 & \\
\hline \multirow[t]{2}{*}{ PACLLNM } & Exist & 21 & 61.8 & 4 & 18.2 & $<0.001$ \\
\hline & Not exist & 13 & 38.2 & 18 & 81.8 & \\
\hline \multirow[t]{2}{*}{ PALM } & Exist & 7 & 20.6 & 0 & 0 & $0.035^{*}$ \\
\hline & Not exist & 27 & 79.4 & 22 & 100 & \\
\hline \multirow[t]{2}{*}{ PABM } & Exist & 5 & 14.7 & 0 & 0 & $0.145^{*}$ \\
\hline & Not exist & 29 & 85.3 & 22 & 100 & \\
\hline \multirow[t]{4}{*}{ Stage } & I & 10 & 29.4 & 17 & 77.3 & 0.004 \\
\hline & II & 6 & 17.6 & 0 & 0 & \\
\hline & III & 5 & 14.7 & 1 & 4.5 & \\
\hline & IV & 13 & 38.2 & 4 & 18.2 & \\
\hline
\end{tabular}

aChi-square test; *Fisher's exact test; PACLNM — pre-ablation central lymph node metastasis; PACLLNM — pre-ablation cervical lateral lymph node metastasis; PALM — pre-ablation lung metastasis; PABM — pre-ablation bone metastasis

factors in MG and NMG, and comparisons between these two groups afre also illustrated in Table II. We found TS, PAsTg, VI, PACLNM, PACLLNM, PALM, and stage to be statistically significant; whereas age, sex, MF, CI, ETE, and PABM were considered statistically insignificant (Table I, II). Age, PAsTg, and stage III were determined as primary risk factors in metastatic group according to LR analysis (Table III).
Thirty-four cases (61\%) developed metastasis/recurrence, and 22 cases (39\%) had a disease-free (total remission) life. While all the patients in MG had LN metastasis/local recurrence, lung metastasis (seven diffuse, five focal) was observed in $12(21.5 \%)$ cases and bone metastasis in six $(10.5 \%)$ cases during the follow-up. Bone metastases of a patient detected by bone scintigraphy are shown in Figure 2. LN (cervical 
Table III. Risk evaluation with logistical regression analysis in metastatic / recurrent tall cell variant of papillary thyroid cancer Tabela III. Ocena ryzyka za pomocą analizy regresji logistycznej wodmianie wysokokomórkowej przerzutowego/nawrotowego raka brodawkowatego tarczycy

\begin{tabular}{lllll}
\hline Variable (Referans) & B & OR (95\% CI) & p value \\
\hline Age & & -0.170 & $0.844(0.730-0.976)$ & 0.022 \\
\hline PAsTg & 0.133 & $1.143(1.008-1.295)$ & 0.037 \\
\hline Sex (female) & -2.414 & $0.089(0.004-2.074)$ & 0.132 \\
\hline Stage (Stage I) & II & 26.743 & - & \\
\cline { 2 - 4 } & III & 6.151 & $469.1(3.4-64000)$ & 0.014 \\
\cline { 2 - 4 } & IV & 3.949 & $51.9(0.88-3062)$ & 0.058 \\
\hline
\end{tabular}

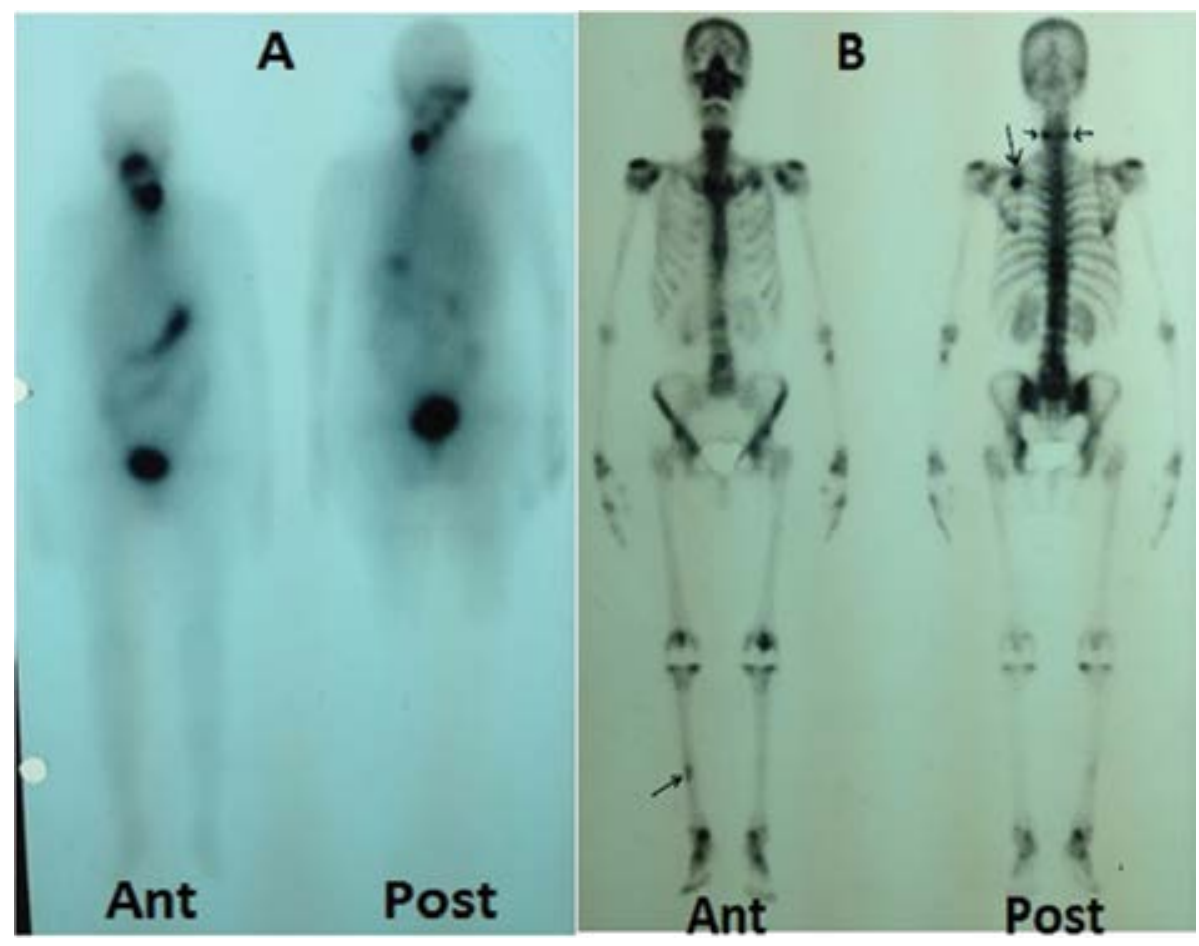

Figure 2. A 72-year-old female patient of TCV with TS: $8 \mathrm{~cm}$, multifocal, CI (+), ETE (+), VI (+), PACLLNM (+), stage IV, PAsTg $>300 \mathrm{ng} / \mathrm{ml}$ was given $9250 \mathrm{MBq}$ (250 mCi) I-131 for ablation. DxWBS at sixth month was negative, but the patient had lung (on HRCT) and bone metastasis (on bone scintigraphy) and $s T g>300 \mathrm{ng} / \mathrm{ml}$. The patient died eight months after the diagnosis. A. RxWB screening test five days after $9250 \mathrm{MBq}$ I-131 ablation therapy exhibited intense uptake in the thyroid bed; B. Bone scintigraphy showed uptakes on upper medial part of left scapula (long arrow) and medial portion of right tibia (long arrow) consistent with bone metastasis Rycina 2. Pacjentka w wieku 72 lat z rozpoznaniem TCV. Wielkość guza: $8 \mathrm{~cm}$, zmiany wieloogniskowe, CI (+), ETE (+), VI (+), PACLLNM (+), stopień IV, PAsTg > $300 \mathrm{ng} / \mathrm{ml}$. Zastosowano ablację I-131w dawce $9250 \mathrm{MBq}$ (250 mCi). Diagnostyczna scyntygrafia całego ciata (DxWBS) po 6 miesiacach była ujemna, jednak u pacjentki stwierdzono przerzuty do ptuc (w tomografii komputerowej wysokiej rozdzielczości HRCT) i kości (w scyntygrafii kości) oraz sTg > $300 \mathrm{ng} / \mathrm{ml}$. Pacjentka zmarta po 8 miesiacach od postawienia diagnozy. A. Badanie RxWBS wykonane 5 dni po ablacji I-131 w dawce 9250 MBq wykazało intensywny wychwyt w loży tarczycy; B. Scyntygrafia kości wykazała ogniska wychwytu w górnej środkowej części topatki (długa strzałka) i środkowej części kości piszczelowej prawej (dluga strzałka) odpowiadające przerzutom do kości

and/or distant) metastasis was detected in $50 \%$ of the patients during the follow-up period. Mean occurrence time of metastasis after diagnosis (disease-free interval) was 24 months (6-60 months). Secondary malignancies developed in six patients during the follow-up. Breast cancer, prostate cancer, lung cancer, and nasopharynx cancer were diagnosed in four cases in MG. Basal cell adenocarcinoma of parotid gland and colon cancer were seen in two cases in NMG. We detected local recurrence/ /LN metastasis and/or distant metastasis (LN, lung, bone) by FDG-PET in seven cases out of nine patients whose DxWBSs were negative. Lung and LN metastases of a patient whose DxWBS was negative were seen on FDG-PET (Figure 3). In these cases Tg levels were 


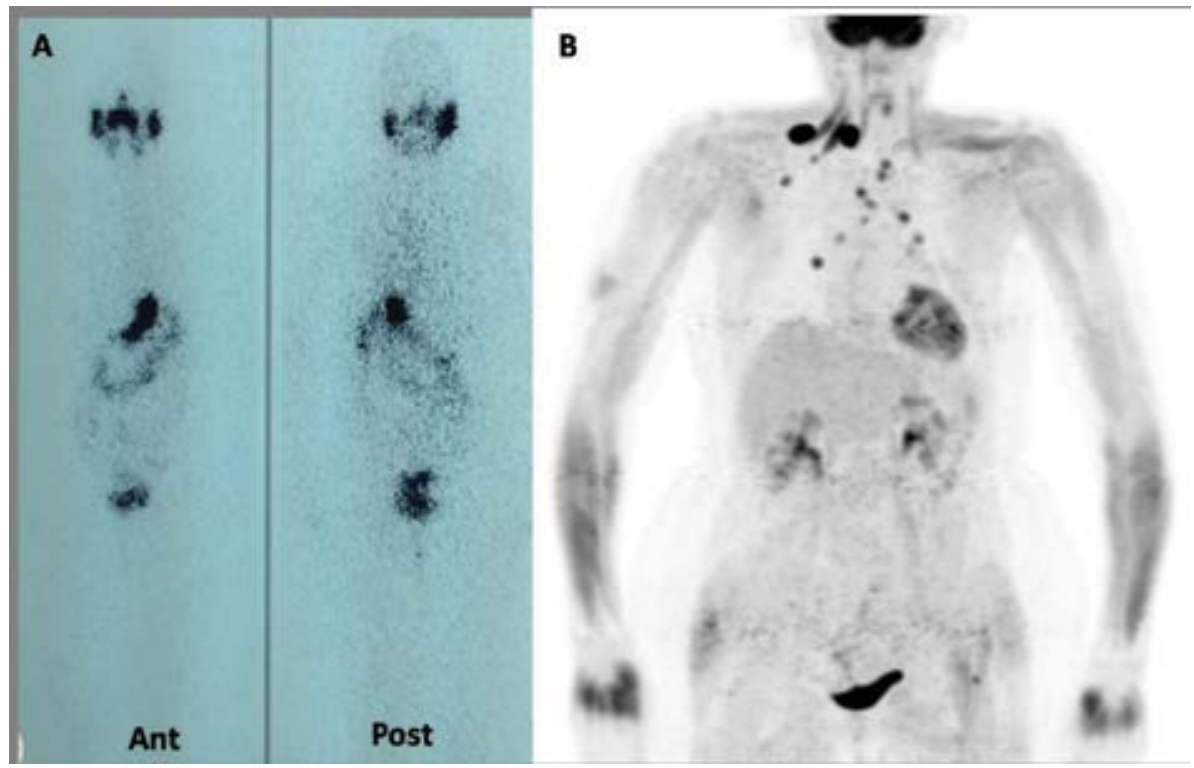

Figure 3. A 61-year-old female patient of TCV with TS: $12 \mathrm{~mm}, \mathrm{CI}(-), \mathrm{VI}(+)$, PACLLNM (+), stage II, PAsTg: $0.2 \mathrm{ng} / \mathrm{ml}$ was given $7400 \mathrm{MBq}(200 \mathrm{mCi})$ I-131 for ablation. She had multiple distant lymph nodes and multiple nodular lung metastasis seven years later (on FDG-PET). A. DxWBS was negative and sTg: $0.9 \mathrm{ng} / \mathrm{ml}$; B. Multiple metastatic lymph nodes in right supraclavicular region (SUV max: 28.6) and multiple metastatic nodular lung metastasis, as the largest in the anterior segment of the right upper lung (SUV max: 6.6), were seen on FDG-PET MIP images

Rycina 3. Pacjentka w wieku 61 lat z rozpoznaniem TCV. Wielkość guza: 12 mm, CI (-), VI (+), PACLLNM (+), stopień II, PAsTg: 0,2 ng/ml. Zastosowano ablację I-131 w dawce $7400 \mathrm{MBq}(200 \mathrm{mCi}$ ). Po 7 latach u chorej stwierdzono liczne przerzuty w odległych węzłach chtonnych oraz ptucach (w badaniu FDG-PET). A. W badaniu DxWBS uzyskano wynik ujemny, a sTg wynosiło 0,9 ng/ml; B. W badaniu FDG-PET MIP widoczne liczne przerzutowe węzły chłonne w prawej okolicy nadobojczykowej (SUV max: 28,6) oraz liczne guzowate przerzuty w płucach, $w$ tym największy w segmencie przednim górnego płata prawego płuca (SUV max: 6,6)

substantially high, leading us to consider possible metastasis. They were treated by higher I-131 doses after surgical excision. In two cases in which both FDG-PET and DxWBS were negative, a persistently high $\operatorname{Tg}$ (1386 $\mathrm{ng} / \mathrm{ml}$ ) level was the only indicator of metastasis in one of the cases. In another case with negative DxWBS, bone scintigraphy detected vertebral metastasis, and therefore radiotherapy was required.

Nine patients in the MG died due to the disease and disease-related complications. Two out of these nine patients died of brain metastasis; while the rest of them died because of cardiopulmonary disorders caused by the disease and its complications. The only patient who died in the NMG was a female aged 80 years, and probably she did not die of TCV. In the cases who died in the MG, mean age was 65 years, mean TS was $42 \mathrm{~mm}$, and mean PAsTg was $684 \mathrm{ng} / \mathrm{ml} ; 55.5 \%$ of the patients were male; $55.5 \%$ of the tumours were multifocal, $66.5 \% \mathrm{CI}(+), 33.5 \%$ ETE $(+)$, and $77.5 \% \mathrm{VI}$ $(+) ; 55.5 \%$ of the patients were PACLNM $(+), 66.5 \%$ PACLLNM (+), 55.5\% PALM (+), and 55.5\% PABM $(+) ; 77.5 \%$ of the patients were at stage IV; mean administered dose was $17464 \mathrm{MBq}$; and the mean study period was 81 months.

\section{Discussion}

In spite of some recent studies claiming that TCV histology does not adversely affect the prognosis, TCV itself is still a negative prognostic indicator [19]. Although studies on the prognosis of TCV and other stubborn variants have been performed, knowledge about their biological behaviour remains unclear because of the lack of studies involving a large number of patients [20]. The studies in the literature related to TCV almost always compared it with its PTC patient population with regard to risk factors and clinicopathological features. Our study is the first one in the literature in which metastatic and non-metastatic subgroups of TCV were followed-up for a long time and were compared with each other regarding well-known risk factors. We also studied some additional risk factors that were not used in other studies when comparing these two groups.

TCV incidence in our patient population (3.2\%) was below the incidence in the literature in general. The mean age of patients with TCV in reported series are around 53 years $[9,10]$ whereas the mean age of our patients (49 years) was lower than the literature. We attribute this fact to the early diagnosis by improved 
health services and elaborate patient screening with delicate medical instruments in our hospital. The series in the literature suggest a higher rate of recurrence in $\mathrm{TCV}$, which is probably relevant to the older age (over 50 years) at diagnosis [20]. Burman et al. reviewed 76 patients with TCV and concluded that patients older than 50 years appeared more likely to have recurrences or die [10]. Although age was not a risk factor alone for metastasis, it was found as a risk factor together with other independent prognostic factors in our study $(p=0.022)$. Male sex according to female sex had been reported as a negative risk factor in the literature $[2,3,9,12]$. We did not find sex as a critical parameter in the MG and NMG both in univariate $(p=0.154)$ and multivariate $(\mathrm{p}=0.132)$ analyses in our study. Mean TS of TCV is higher than PTC. Mean TS of TCV in the study groups are around $4 \mathrm{~cm}[9,10]$. The mean TS of our patients was $27.5 \mathrm{~mm}$, and this was lower than the literature. Again, we regard this with the early diagnosis provided by sophisticated medical devices and techniques leading to the early detection of thyroid pathologies. Mean TS was higher in the MG, and it was a significant risk factor in the study.

Michels et al. observed that TCV was slightly more multifocal than PTC in a cohort study of 778 patients with DTC [5]. In our study, 53.5\% of the cases were multifocal, and we observed that MF did not constitute a risk factor for metastasis $(p=0.505)$. CI seems to be a more frequent pathologic feature in TCV than PTC. However, in our study, although CI was positive in $64 \%$ of the patients, it was not statistically significant $(p=0.073)$ between MG and NMG with regard to metastasis. Higher incidence of ETE in TCV patients was reported in the literature $[5,21-23]$. Prendville et al. found ETE in $65 \%$ of their TCV group [24]. In our study, 35.5\% of the cases had ETE and we found that it was not a risk factor for metastasis $(p=0.625)$. VI is not considered as a negative prognostic indicator in PTC. Hay et al. found that the presence of angioinvasion was not a significant factor in their cohort study of 1779 patients with PTC [25]. VI positivity is more common in TCV [18]. 37.5\% of our patients had VI. On the other hand, we concluded that VI was a risk factor between MG and NMG in our study.

Higher incidence rates of pre-ablation LN metastasis in TCV patients were reported in the literature $[14,18,19,26,27]$. There were central LN metastases in $37.5 \%$, and lateral cervical LN metastasis in $44.5 \%$ of our cases. We found PACLNM and PACLLNM to be statistically significant in our study. It is remarkable that PACLLNM was slightly more sensitive than PACLNM. It was stated in the literature that TCV had more distant metastases than DTC [14, 18, 27, 28]. 12.5\% of our patients had lung metastasis (detected by RxWBD or HRCT), and $9 \%$ had bone metastasis before the ablation therapy (detected by RxWBS, later supported by bone scintigraphy and MRI). PALM was proven as a risk factor in our study. Nevertheless, PABM was not a risk factor $(p=0.145)$, surprisingly. This inappropriate result can be simply explained by inadequate sampling number.

TCV patients present with advanced disease (stage III or IV) more often. Poor prognosis of TCV is frequently associated with stage. Recent large series support the thesis that poor prognosis is linked mainly to the stage $[23,28]$. We determined stage as a very important independent risk factor in the study. While stage III seemed to be a metastatic risk factor in our study $(\mathrm{p}=0.004)$, stage IV interestingly was not ( $p=0.058)$, in multivariate analysis. A possible explanation for this discrepancy is insufficient sampling number in stage IV. If we had had enough patients in stage IV, we could have shown it, too. The circulating amount of $\mathrm{Tg}$ depends on the residual microscopic mass of thyroid tissue left over in the thyroid bed and/or metastatic tumour burden present in a DTC patient with total thyroidectomy $[29,30]$. It is well documented in the literature that high PAsTg reflecting indirectly the existence of tumoural cells somewhere is a very important marker as a negative prognostic factor in PTC. This fact was somewhat accentuated for TCV. The mean PAsTg level of our patient group was $290.5 \mathrm{ng} / \mathrm{ml}$, and we found PAsTg to be the most acute risk factor acting on metastasis. It also emerged negatively in this regard upon regression analysis.

Poor prognosis of TCV is certainly associated with grade [5]. But we could not examine the grade, i.e. the percentage of tall cell pattern, as an independent risk factor effecting metastasis in our study because we did not have this parameter definitely in most cases. We also did not compare molecular, genetic, and tumoural factors like Mucl1, type IV collagenase, and B-RAF between MG and NMG because we did not have enough data about these pathologic features. These are the limitations of our study.

In the follow-up, serial neck USG accompanied by $\mathrm{Tg}$ measurement indicated local recurrence and cervical LN metastasis in most of the patients. Even if $\mathrm{Tg}$ levels were in normal range in these patients, they were treated by surgical excision plus high-dose I-131. FDG-PET may detect local recurrence and/or distant metastasis in some patients whose DxWBS are negative but have high Tg levels indicating metastatic suspicion. Older age (over 57 years), larger tumours (over $4.5 \mathrm{~cm}$ ), lenfovascular invasion, and stage IV are well-known poor prognostic factors $[3,6,12]$. In mortal cases of MG, mean age, TS, PAsTg, VI, PALM, PABM, and stage IV rates were seriously high according to survivors in both MG and NMG. Additionally, we found high PAsTg levels (over $400 \mathrm{ng} / \mathrm{ml}$ ) to be an important prognostic factor in terms of mortality. 
Although some recent studies claim that TCV histology does not adversely affect prognosis, TCV is still a negative prognostic indicator in PTC and requires an aggressive therapeutic approach. As possibly as highest ablation doses (up to 9250-11110 MBq [250-300 mCi] calculated according to quantitative tumour or blood/ /whole-body dosimetry) have been recommended for the treatment by American Thyroid Association (ATA). For an absolute follow-up, it must benefit from all means of appropriate imaging methods. FDG-PET/CT plays a very important role in the follow-up of these patients in this sense. It is very useful for the detection of both local recurrence and distant metastasis in patients whose DxWBS and neck USG are negative but who have high Tg levels implying metastasis.

\section{Conclusions}

TS, PAsTg, VI, PACLNM, PACLLNM, PALM, and stage are independent risk factors alone for TCV. However, age, PAsTg, and stage are more effective in metastatic development. Higher ablation doses should be administered to TCV patients having advanced stage (III, IV), high pre-ablation thyroglobulin level (over $400 \mathrm{ng} / \mathrm{ml}$ ), and older age (over 52 years) especially with large tumour size (over $3.5 \mathrm{~cm}$ ) and initial cervical lymph node metastasis.

\section{Conflict of interest}

None.

\section{Acknowledgments}

Statistical analyses of this study were performed by Turker Turker, Associate Professor, Department of Epidemiology, Gulhane Training and Research Hospital. We would like to thank him for his contribution.

\section{References}

1. Hawk WA, Hazard JB. The many appearances of papillary carcinoma of the thyroid. Cleve Clin Q. 1976; 43(4): 207-215, indexed in Pubmed: 1000814.

2. Jalisi S, Ainsworth T, Lavalley M. Prognostic outcomes of tall cell variant papillary thyroid cancer: a meta-analysis. J Thyroid Res. 2010; 2010: 325602, doi: 10.4061/2010/325602, indexed in Pubmed: 21048837.

3. Johnson TL, Lloyd RV, Thompson NW, et al. Prognostic implications of the tall cell variant of papillary thyroid carcinoma. Am J Surg Pathol. 1988; 12(1): 22-27, indexed in Pubmed: 3337337.

4. Rüter A, Nishiyama R, Lennquist S. Tall-cell variant of papillary thyroid cancer: disregarded entity? World J Surg. 1997; 21(1): 15-20; discussion 20, indexed in Pubmed: 8943172.

5. Michels JJ, Jacques M, Henry-Amar M, et al. Prevalence and prognostic significance of tall cell variant of papillary thyroid carcinoma. Hum Pathol. 2007; 38(2): 212-219, doi: 10.1016/j.humpath.2006.08.001, indexed in Pubmed: 17097131.

6. Ghossein RA, Leboeuf $\mathrm{R}$, Patel $\mathrm{KN}$, et al. Tall cell variant of papillary thyroid carcinoma without extrathyroid extension: biologic behavior and clinical implications. Thyroid. 2007; 17(7): 655-661, doi: 10.1089/ thy.2007.0061, indexed in Pubmed: 17696836.

7. Segal K, Friedental R, Lubin E, et al. Papillary carcinoma of the thyroid. Otolaryngol Head Neck Surg. 1995; 113(4): 356-363, indexed in Pubmed: 7567004
8. Adeniran AJ, Zhu Z, Gandhi M, et al. Correlation between genetic alterations and microscopic features, clinical manifestations, and prognostic characteristics of thyroid papillary carcinomas. Am J SurgPathol. 2006; 30(2): 216-222, doi: 10.1097/01.pas.0000176432.73455.1b, indexed in Pubmed: 16434896.

9. Ghossein R, Livolsi VA. Papillary thyroid carcinoma tall cell variant. Thyroid. 2008; 18(11): 1179-1181, doi: 10.1089/thy.2008.0164, indexed in Pubmed: 18925842

10. Burman KD, Ringel MD, Wartofsky L. Unusual types of thyroid neoplasms. Endocrinol Metab Clin North Am. 1996; 25(1): 49-68, doi: 10.1016/ s0889-8529(05)70312-1, indexed in Pubmed: 8907680.

11. Rivera M, Ghossein RA, Schoder H, et al. Histopathologic characterization of radioactive iodine-refractory fluorodeoxyglucose-positron emission tomography-positive thyroid carcinoma. Cancer. 2008; 113(1): 48-56, doi: 10.1002/cncr.23515, indexed in Pubmed: 18484584.

12. Leung AKC, Chow SM, Law SCK. Clinical features and outcome of the tall cell variant of papillary thyroid carcinoma. Laryngoscope. 2008; 118(1): 32-38, indexed in Pubmed: 18025951.

13. Solomon A, Gupta PK, LiVolsi VA, et al. Distinguishing tall cell variant of papillary thyroid carcinoma from usual variant of papillary thyroid carcinoma in cytologic specimens. Diagn Cytopathol. 2002; 27(3): 143-148, doi: 10.1002/dc.10156, indexed in Pubmed: 12203860.

14. Akslen LA, LiVolsi VA. Prognostic significance of histologic grading compared with subclassification of papillary thyroid carcinoma. Cancer. 2000; 88(8): 1902-1908, doi: 10.1002/(sici)1097-0142(20000415)88:8<1902::aidcncr20>3.3.co;2-p, indexed in Pubmed: 10760768.

15. Montone KT, Baloch ZW, LiVolsi VA. The thyroid Hürthle (oncocytic) cell and its associated pathologic conditions: a surgical pathology and cytopathology review. Arch Pathol Lab Med. 2008; 132(8): 1241-1250, indexed in Pubmed: 18684023.

16. Wreesmann VB, Sieczka EM, Socci ND, et al. Genome-wide profiling of papillary thyroid cancer identifies MUC1 as an independent prognostic marker. Cancer Res. 2004; 64(11): 3780-3789, doi: 10.1158/0008-5472. CAN-03-1460, indexed in Pubmed: 15172984.

17. Campo E, Merino MJ, Liotta L, et al. Distribution of the 72-kd type IV collagenase in nonneoplastic and neoplastic thyroid tissue. Hum Pathol. 1992; 23(12): 1395-1401, doi: 10.1016/0046-8177(92)90060-g, indexed in Pubmed: 1468777.

18. LiVolsi VA. Papillary carcinoma tall cell variant (TCV): a review. Endocr Pathol. 2010; 21(1): 12-15, doi: 10.1007/s12022-010-9106-y, indexed in Pubmed: 20174895

19. LiVolsi VA. Surgical Pathology of the Thyroid. Philadelphia: WB Saunders Company. ; 1990: 136-163.

20. Terry JH, St John SA, Karkowski FJ, et al. Tall cell papillary thyroid cancer: incidence and prognosis. Am J Surg. 1994; 168(5): 459-461, doi: 10.1016/ s0002-9610(05)80099-6, indexed in Pubmed: 7977973.

21. Ain KB. Papillary thyroid carcinoma. Etiology, assessment, and therapy. Endocrinol Metab Clin North Am. 1995; 24(4): 711-760, indexed in Pubmed: 8608778 .

22. Ostrowski ML, Merino MJ. Tall cell variant of papillary thyroid carcinoma: a reassessment and immunohistochemical study with comparison to the usual type of papillary carcinoma of the thyroid. Am J Surg Pathol. 1996; 20(8): 964-974, doi: 10.1097/00000478-199608000-00005, indexed in Pubmed: 8712296.

23. Moreno Egea A, Rodriguez Gonzalez JM, Sola Perez J, et al. Prognostic value of the tall cell variety of papillary cancer of the thyroid. Eur J Surg Oncol. 1993; 19(6): 517-521, indexed in Pubmed: 8270036.

24. Prendiville S, Burman KD, Ringel MD, et al. Tall cell variant: an aggressive form of papillary thyroid carcinoma. Otolaryngol Head Neck Surg. 2000; 122(3): 352-357, doi: 10.1016/S0194-5998(00)70047-7, indexed in Pubmed: 10699809.

25. Hay ID, Bergstralh EJ, Goellner JR, et al. Predicting outcome in papillary thyroid carcinoma: development of a reliable prognostic scoring system in a cohort of 1779 patients surgically treated at one institution during 1940 through 1989. Surgery. 1993; 114(6): 1050-7; discussion 1057, indexed in Pubmed: 8256208.

26. Ito Y, Hirokawa M, Uruno T, et al. Prevalence and biological behaviour of variants of papillary thyroid carcinoma: experience at a single institute. Pathology. 2008; 40(6): 617-622, doi: 10.1080/00313020802320630, indexed in Pubmed: 18752130.

27. Bocklage T, DiTomasso JP, Ramzy I, et al. Tall cell variant of papillary thyroid carcinoma: cytologic features and differential diagnostic considerations. Diagn Cytopathol. 1997; 17(1): 25-29, doi: 10.1002/(sici)10970339(199707)17:1<25::aid-dc5>3.3.co;2-w, indexed in Pubmed: 9218899.

28. Wenig BM, Thompson LD, Adair CF, et al. Thyroid papillary carcinoma of columnar cell type: a clinicopathologic study of 16 cases. Cancer. 1998; 82(4): 740-753, doi: 10.1002/(sici)1097-0142(19980215)82:4<740::aidcncr18>3.0.co;2-y, indexed in Pubmed: 9477108.

29. Evans C, Tennant S, Perros P, et al. Thyroglobulin in differentiated thyroid cancer. Clin Chim Acta. 2015; 444: 310-317, doi: 10.1016/j. cca.2014.10.035, indexed in Pubmed: 25444737.

30. Zucchelli G, Iervasi A, Ferdeghini M, et al. Serum thyroglobulin measurement in the follow-up of patients treated for differentiated thyroid cancer. Q J Nucl Med Mol Imaging. 2009; 53(5): 482-489, indexed in Pubmed: 19910901. 